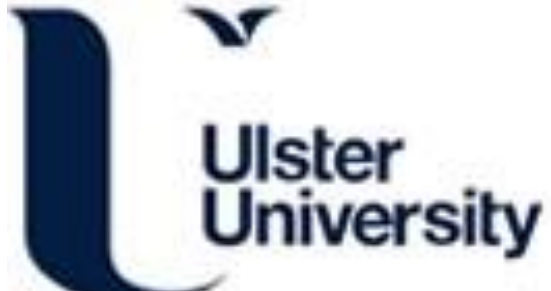

\section{Australia's National Human Rights Action Plans: traditional or modern model of planning?}

Chalabi, A. (2016). Australia's National Human Rights Action Plans: traditional or modern model of planning? International Journal of Human Rights, 20(7), 993-1017. https://doi.org/10.1080/13642987.2016.1196191

Link to publication record in Ulster University Research Portal

\section{Published in:}

International Journal of Human Rights

Publication Status:

Published online: 05/07/2016

DOI:

10.1080/13642987.2016.1196191

\section{Document Version}

Author Accepted version

\section{General rights}

Copyright for the publications made accessible via Ulster University's Research Portal is retained by the author(s) and / or other copyright owners and it is a condition of accessing these publications that users recognise and abide by the legal requirements associated with these rights.

\section{Take down policy}

The Research Portal is Ulster University's institutional repository that provides access to Ulster's research outputs. Every effort has been made to ensure that content in the Research Portal does not infringe any person's rights, or applicable UK laws. If you discover content in the Research Portal that you believe breaches copyright or violates any law, please contact pure-support@ulster.ac.uk. 
This is an Accepted Manuscript of an article published by Taylor \& Francis in the international Journal of Human Rights on 5 July 2016, available online:

http://www.tandfonline.com/doi/full/10.1080/13642987.2016.1196191

To cite this article: Azadeh Chalabi (2016): Australia's National Human Rights Action Plans: traditional or modern model of planning?, The International Journal of Human Rights, DOI:

10.1080/13642987.2016.1196191

\title{
Australia's National Human Rights Action Plans: Traditional or Modern Model of Planning?
}

\author{
Azadeh Chalabi \\ a.chalabi@ulster.ac.uk \\ School of Law and Transitional Justice Institute, Ulster University, UK
}

\begin{abstract}
This inquiry has sought to assess for the first time the effectiveness of three Australia's National Human Rights Action Plans (NHRAP) in realizing human rights and show that among other factors, the traditional concept of planning, which is still predominant in international human rights law, can play a key part in generating different problems in the way of an effective action plan. This focused case study was informed by four sources of data, including an online survey of 37 experts, an in-depth interview and secondary data, qualitative and quantitative. As the results of this this mixed methods research indicate, the first two of Australia's NHRAPs were only 'slightly effective' in implementing human rights. These two plans are beset by six fundamental and four subordinate problems which all stem from, inter alia, traditional planning. On the contrary, the current Australia's current NHRAP which steps away from the very nature of traditional planning is more effective than the first two. The current experience of Australia, particularly in the areas of women's rights and children's rights, has a number of important implications for future practices. These include, but are not limited to, conducting a baseline study, linkage to the UPR, evidence-based, theoretical foundation, extensive consultation and integrated governance approach. This all suggests a strategic shift towards the modern model of planning which is multi-level, participatory, top-down bottom-up and theory laden.
\end{abstract}

\section{Introduction}


Currently, under all the nine core human rights treaties, states parties have an immediate obligation to adopt an action plan for the realisation of the rights contained in the conventions. ${ }^{1}$ The Vienna Declaration and Programme of Action adopted at World Conference on Human Rights in 1993 also recommended each state to develop a National Human Rights Action Plan (NHRAP) for implementing 'human rights' in general. Although these plans have been pursued by many countries at considerable effort and expense, very little has been written on NHRAPs and the critical question is how effective has been the implementation of such plans for realising human rights and what is the concept of planning behind NHRAPs?

To address the question, I conducted an in-depth case study of three NHRAPs in Australia which is the world-leader in the formulation of such plans. Australia is selected purposefully on the basis of four criteria, including (1) available in English language, (2) a rich background in developing and implementing NHRAPs, (3) having one or more informative NHRAP(s) (not a very short one), and (4) the level of development of the country concerned. Australia is not merely the country which first proposed the concept of NHRAP at the Vienna Conference but also it developed the World's first NHRAP, as recommended at the Vienna Conference, in 19931994. Ten years later, in 2004, the Government reaffirmed Australia's commitment to the protection of human rights, through the development of the second Australian NHRAP. In December 2012, the Australian Government has released its third and current NHRAP. Moreover, Australia has been, at least for nine years, from 2005 to 2013, the second most developed country in the world. ${ }^{2}$

This article proceeds as follows. Section $\Pi$ introduces and compares the traditional and modern concepts of planning. Section III walks through the method used in this research. Section IV provides a brief profile of developing three NHRAPs in Australia. Section V assesses the effectiveness of Australia's NHRAPs in implementing human rights and seeks to examine what seems to be the central proposition at stake; namely that the traditional model of planning can generate or reinforce many problems in the way of an effective action plan for implementing human rights. Section VI concludes.

\section{Human Rights Planning: Traditional vs. Modern}


In general, there are two concepts of planning: traditional and modern. The traditional concept of planning is defined as a top-down technocrat activity of finding the best means for the ends. ${ }^{3}$ It was the dominant theory for planning up until early 1980s. Traditionally, planning is statecentric and theory-neutral. ${ }^{4}$ More specifically, this model of planning is based on a distinction between substantive and procedural theory. It just focuses on the 'process' of finding the means as the business of planning while politicians and others set the ends in advance. ${ }^{5}$ This concept of planning also assumes that the political establishment is perfect and there is a general agreement on values in society. ${ }^{6}$ As John Friedmann states:

The old view of planning was of a relatively static world in which planners were objective analysts who had access to pertinent knowledge about the future and could effectively communicate what they knew to political decisionmakers through written documents, such as policy drafts or a plan. The articulation of values implicit in this view was not the planners' responsibility but politicians'. Planning was understood to be essentially a technical, valuefree activity in the public realm. ${ }^{7}$

As Schonwandt puts it "terms like "public interest" and "the public" were rarely, if ever critically examined by traditional planners, and for the vast majority of them "the public" implied an undifferentiated, homogenous group in which, for example, social, ethnic, or gender differences were seen as unimportant. ${ }^{8}$

Traditional planning was criticised for its assumptions, and for what some have seen as its acceptance of the status quo, and perpetuation of the ruling class values. ${ }^{9}$ Critics argue that this model of planning has a very 'shaky ground' in that it is theory neutral and directed from the top down. ${ }^{10}$ Sandercock accuses planning in its traditional concept of being anti-democratic, raceand gender-blind and culturally homogenising. ${ }^{11}$ This unchecked model of planning allows the States to misuse of their power and thus increases the possibility of corruption.

In the current literature on planning, by contrast, a modern concept of planning is participatory, multilevel, top-down bottom-up and theory-laden. ${ }^{12}$ Unlike traditional planning, the scope of cooperation in the modern planning is not solely defined by government. In modern planning, ideally, all the stakeholders, from the local to the global should get involved in the identification 
of problems in the preparatory phase, the development of the plan, implementation, monitoring and the evaluation of the plan. Modern planning is based on a top-down bottom-up strategy which includes the advantages of both the superior vast knowledge and expertise of experts who have clear ideas about different phases of planning and human rights from the top-down and the detailed wisdom located in the community itself from the bottom-up so that the direction of planning and development can be directed by both experts and those most affected. ${ }^{13}$ Modern planning is conceived as a linkage between knowledge and action. ${ }^{14}$ Planning should be derived from a theory and thus before any human rights planning, both procedural and substantive theories should be set. ${ }^{15}$ Otherwise, planning as a form of practice, without theory will be blindthere will be no frame of reference for baseline studies, developing the content, monitoring and evaluation. ${ }^{16}$ As Jim Ife argues, "if practice is totally divorced from theory it leads to an unthinking anti-intellectualism. Frames of reference and critical reflection are gone and one simply does, for the sake of doing., 17

Substantive theory provides the knowledge base to inform what the content should be. ${ }^{18}$ It pertains to interdisciplinary knowledge relevant to the content of planning and should be a theory which is the most relevant to the issue under consideration. Procedural theory, on the other hand, defines and justifies the process of planning and concerns how to transfer knowledge (substantive theory) into action. ${ }^{19}$

Ernest R. Alexander in his book Approaches to Planning argues that planning should be informed by theory. ${ }^{20} \mathrm{He}$ emphasises that the relationship between theory and action is very important for planning because it is ultimately a prescriptive, not a descriptive, activity. ${ }^{21}$ As Campbell and Fainstein in Readings in Planning Theory put it 'planning theory is not just some idle chatting at the margins of the field. If done poorly, it discourages and stifles; but if done well, it defines the field and drives it forward. ${ }^{22}$

Nevertheless, all the materials, directly or indirectly concerned with the obligation to adopt a NHRAP, reflect the fact that the traditional model of planning is still predominant in international human rights law and most states have developed their plans in accordance with the traditional understanding of planning. ${ }^{23}$ This is also true of Australia. In what follows, an attempt shall be made to unravel the impact of traditional planning on the effectiveness of NHRAPs in 
the case of Australia and provide clear lessons for future practices. Let me start with the methods employed in this case study.

\section{Research Method}

Based on mixed methods strategy, this inquiry utilises two sets of data. The first set, which is primary data, includes an online survey and an interview and the second contains secondary data, both qualitative and quantitative.

\section{A. Online Survey}

In 2013, an online survey of the "Australia's National Human Rights Action Plans in Practice" was conducted. It was ran from April to July 2013. The survey was programmed in Survey Gizmo, with human rights experts invited to participate by email. It consisted of six sections and 37 questions including multiple choice questions, ranking and open-ended questions.

This research was based on a purposive sampling. Almost all the principal human rights organizations, governmental and non-governmental, who have closely worked on the process of developing NHRAPs in Australia, participated in this survey. ${ }^{24} 30.3$ percent of the survey respondents were from non-governmental organizations, 15.2 percent from governmental organizations, 45.5 percent from academic organizations, 3.0 percent from independent consultants and 6.0 percent others.

In general, 37 'completed responses' ${ }^{25}$ are collected. Data analysis focused solely on the completed responses. Of this number (37 respondents), 59.4 percent are either quite or very familiar with NHRAPs. 27 percent are not very familiar and 13.5 percent of the respondents are not at all familiar with such plans. In other words, only five respondents (out of 37) were not at all familiar with NHRAPs and 22 respondents were quite or very familiar with them. This 
suggested that participant recruitment was successful in yielding a group who were generally an expert in the area of NHRAPs. The five respondents who were 'not at all familiar' with NHRAPs were removed from analysis.

It should be noted that the results of this survey is based on the 'expert knowledge' (informed knowledge) of those who participated in this survey. There is a big difference between 'opinion' (subjective knowledge) and 'expert knowledge' (objective knowledge). Unlike opinion which is purely subjective, expert knowledge is based on expertise and thus is scientifically reliable.

\section{B. Interview}

This research also included an interview with Bill Barker who wrote the UN Handbook on NHRAPs in 2002. In the lead up to the 1993 World Conference on Human Rights, he suggested the idea of the development of NHRAPs, which was subsequently adopted by the Conference. ${ }^{1} \mathrm{~A}$ two-hour interview was conducted in London in October 2013. Some questions were also asked via email.

\section{Secondary Analysis}

To complement the primary data, this study contains a secondary analysis of both qualitative and quantitative data from a variety of sources such as joint NGO report, the National Human Rights Consultation report, the Australian Bureau of Statistics, Immigration Detention and Community Statistics, Australia's Baseline Study, NGO submissions on the Baseline study, Human Development report and Gender Empowerment Measure.

\section{Past and Current Experience: A Short Profile}

\footnotetext{
${ }^{1}$ For many years, Bill Barker served as Australia's representative to the United Nations' human rights bodies in Geneva and New York. He has been also acting as an international human rights consultant for formulating NHRAPs in many countries.
} 


\section{A. The First Two Plans}

The first Australian NHRAP consisted of a 127-page document. It is the very first national action plan for implementing human rights in the world developed as recommended in the Vienna World Conference on Human Rights. The Australian plan was drafted within a tight time-frame of several months so that it could be presented to the Commission on Human Rights at its fiftieth session in 1994. While the plan itself does not indicate how it was prepared, it was developed in late 1993 by an interdepartmental committee of government officials, led by the Department of Foreign Affairs and Trade and the Attorney-General's Department. ${ }^{26}$ The plan was made publicly available, although there was no media campaign associated with its launch. In a discussion paper prepared for the Australian Human Rights Commission (AHRC), Bill Barker explains that:

Australia had advanced the concept of national action plans in the context of the World Conference with the idea that it would be implemented by other countries, not by Australia. However it was apparent that, having successfully pushed for endorsement, Australia had to demonstrate credibility by preparing and adopting its own plan. Given that the next session of the UN's Commission on Human Rights was to take place in February 1994, this became a target date. Australia's 'National Action Plan' was duly launched in January 1994 and was submitted to the 1994 Session of the Commission on Human Rights. ${ }^{27}$

The plan includes a 'Foreword' by the Acting Prime Minister of Australia, who described the plan as a "clear statement of Australia's commitment to the protection and implementation of human rights at a national level". While the plan itself does not contain any time frame, other Government statements indicated that it was intended to cover the five-year period from 1994 to $1998 .^{28}$

Due primarily to the haste at which this plan was developed, it had very little impact, if any, on promoting and protecting human rights in Australia. ${ }^{29}$ As Bill Barker further argues the main purpose of the plan was to deposit the first NHRAP with the UN Commission on Human Rights 
by February 1994, rather than to bring about improvements in human rights observance in Australia. ${ }^{30} \mathrm{He}$ believes that "while the objective of submitting a national action plan to the United Nations as quickly as possible was a worthy one, the ultimate impact could well have been greater if Australia had taken an extra year to work on the plan, to conceptualise it effectively, to consult widely and to ensure that it was better established on human rights principles and managerial structures. It would certainly have had a greater impact within Australia itself.' ${ }^{31}$ As the first Australia's NHRAP was more a symbolic plan than an effective one, the following parts of this paper shall more focus on the second and third Australia's NHRAPs.

The second Australia's NHRAP was developed in 2004. This plan was formulated in a 115-page document. It consisted of two parts and two Annexures; the parts include 'Overview' and 'Human Rights in Australia' and the Annexures contain 'The protection of human rights in Australia' and 'International Human Rights treaties to which Australia is a party'. There seems to be an uncertainty about the purpose behind the 2004 plan though. Even the title was changed from 'Australia's National Action Plan on Human Rights' in its draft to 'Australia's National Framework for Human Rights: National Action Plan' in its final version. As Bill Barker states this change had the twin defects that it blurred the focus on what the document was supposed to be while at the same time making the title unmanageable. ${ }^{32}$ The author of the UN handbook on NHRAPs believes that 'it seems likely the main purpose was simply to set out a robust defence of Australia's human rights credentials and not human rights improvements in Australia. ${ }^{33}$

\section{B. The Current Plan}

In January 2011, Australia appeared before the United Nations Human Rights Council for its inaugural Universal Periodic Review (UPR). In June 2011, Australia made its formal response to the 145 recommendations made by the United Nations Members' States and later that month, the Australian Government committed to incorporating the UPR recommendations into its new NHRAP. More than a year later, in December 2012, Australia released its third NHRAP. This plan is contained in an 87-page document and consists of four general sections including:

1. Protection and promotion of human rights in Australia 
2. The human rights concerns of the general community

3. The human rights experience of specific groups in Australia

4. Monitoring

The third section is the longest and most important section encompassing nine sub-sections i.e., (1) Aboriginal and Torres Strait Islander peoples, (2) women, (3) Children and young people, (4) Older People, (5) People at risk of or experiencing homelessness, (6) People with disability, (7) Carers, (8) People in prisons, and (9) Refugees, asylum seekers, migrants and people from culturally and linguistically diverse backgrounds.

Each section is structured through a table consists of four parts, including; (1) 'priority area', (2) 'Action', (3) 'Legal Agency/Jurisdiction', and (4) 'Performance indicators/timeline'. However, only 9 per cent of the 'action' items contain 'performance indicators' and only 35 per cent identify a timeframe for implementation. Overall, it presents a commendable list of 355 actions.

\section{The Effectiveness of NHRAPs}

Effectiveness of a NHRAP refers to the extent to which these plans improve the realization of human rights in different areas (such as women's rights, children's rights, immigrants' rights) set forth in the plan. To assess the actual effectiveness of a plan requires a lag time that is long enough to ensure that the actual impact can be measured. The approach adopted here with respect to the first two plans stresses the actual (not potential) impact of the plans on realising human rights in Australia as enough time has passed since implementing the plans in practice. Nonetheless, as for the current Australia's NHRAP, the main focus is on the potential (not actual) impact of the plan on realising human rights. This is due to the fact that the actual effects of the current plan which was released in December 2012 and includes some goals for 2018 and beyond, take time to appear.

\section{A. The First Two Plans}


Due to the importance of human rights education in implementing human rights, survey respondents were asked about the effectiveness of the first two NHRAPs, especially the 2004 plan, in the promotion of greater awareness of human rights in different areas. The result is presented in the table below.

As table 1 shows, the 'immigration and asylum' constitute the least effective, and 'law enforcement' the most effective area in which the first two plans (especially the 2004 NHRAP) could promote greater awareness of human rights.

Most importantly, one of the key questions in the online survey, conducted in this study, was about the effectiveness of the first two NHRAPs, especially the second NHRAP, in implementing various rights in Australia. The responses indicate that the least effective part of the first plans, especially the 2004 plan, is in the area of immigration and asylum (Table 2). This is because of the fact that no reference was made to the rights of refugees and asylum seekers in the main text of the plan. In the "Annexure A" (not the main text), nevertheless, the 2004 plan only sought to justify some existing anti-rights laws and policies in this area. It reiterated that 'under the Act [the Migration Act 1958 (Cth)], immigration detention of all unlawful noncitizens in mainland Australia is mandatory by operation of law'. ${ }^{34}$

It should be noted that the Migration Act 1958, supported by the plan, requires all unlawful noncitizens (other than those in excised offshore zones) to be detained, regardless of circumstances, until they are granted a visa or removed from Australia. It provides that a stateless person who has committed no crime, and who has requested removal from Australia and is cooperating with the authorities, may be kept in immigration detention for the rest of their life if unable to be deported or removed. This Act has been strongly criticised by international human rights bodies and NGOs. ${ }^{35}$ 
Table 1: Online survey participants' views on the effectiveness of the first two NHRAPs (especially the $\mathbf{2 0 0 4}$ plan) in the promotion of greater awareness of human rights in different areas

\begin{tabular}{|c|c|c|c|c|c|c|c|}
\hline & $\begin{array}{c}\text { Extremely } \\
\text { ineffective }\end{array}$ & Ineffective & $\begin{array}{c}\text { Slightly } \\
\text { effective }\end{array}$ & Effective & $\begin{array}{c}\text { Extremely } \\
\text { effective }\end{array}$ & $\begin{array}{c}\text { Don't } \\
\text { know }\end{array}$ & Responses \\
\hline The general public & $21.8 \%$ & $25.0 \%$ & $49.9 \%$ & $0.0 \%$ & $0.0 \%$ & $3.1 \%$ & 32 \\
\hline Law enforcement & $13.3 \%$ & $6.7 \%$ & $63.3 \%$ & $3.3 \%$ & $0.0 \%$ & $13.3 \%$ & 30 \\
\hline Social work & $6.5 \%$ & $12.9 \%$ & $58.1 \%$ & $0.0 \%$ & $0.0 \%$ & $22.6 \%$ & 31 \\
\hline Education & $6.5 \%$ & $25.8 \%$ & $48.4 \%$ & $3.2 \%$ & $3.2 \%$ & $12.9 \%$ & 31 \\
\hline $\begin{array}{c}\text { Law courts } \\
\text { Administration of } \\
\text { Justice }\end{array}$ & $13.3 \%$ & $23.3 \%$ & $40.0 \%$ & $3.3 \%$ & $0.0 \%$ & $20.0 \%$ & 30 \\
\hline $\begin{array}{c}\text { Immigration and } \\
\text { asylum }\end{array}$ & $25.0 \%$ & $18.8 \%$ & $50.0 \%$ & $0.0 \%$ & $0.0 \%$ & $6.3 \%$ & 32 \\
\hline $\begin{array}{c}\text { Employment } \\
\text { Government/cabinet }\end{array}$ & $12.5 \%$ & $21.9 \%$ & $46.9 \%$ & $0.0 \%$ & $0.0 \%$ & $18.8 \%$ & 32 \\
\hline Health care & $6.3 \%$ & $15.6 \%$ & $50.0 \%$ & $6.3 \%$ & $0.0 \%$ & $21.9 \%$ & 32 \\
\hline Average & $12.1 \%$ & $20.4 \%$ & $49.5 \%$ & $2.2 \%$ & $0.0 \%$ & $15.3 \%$ & 32 \\
\hline
\end{tabular}

Most significantly, the mandatory detention of children has constituted a clear breach of the Convention on the Rights of the Child (CRC), which Australia ratified in 1990. Whereas between 1999 and 2003, 2184 children were held in immigration detention (of whom 92 percent were subsequently found to be refugees) and the mandatory detention of asylum seeker children raised perhaps the most fervent criticism of Australia's practices in terms of refugees' rights, markedly this pressing human rights issue was not even mentioned in the plan. ${ }^{36}$ As stated in the HREOC report, children in long-term detention in Australia had suffered from:

anxiety, distress, bed-wetting, suicidal ideation and self-destructive behaviour including attempted and actual self-harm. The methods used by children to self-harm have included attempted hanging, slashing, swallowing shampoo or detergents and lip-sewing. ${ }^{37}$ 
The failure to even address the issue, as a serious issue warranting extended discussion and further exploration, is a manifest failure of this plan.

Table 2: Online survey participants' views on the effectiveness of the first two NHRAPs (especially the 2004 plan) in implementing human rights

\begin{tabular}{|c|c|c|c|c|c|c|c|}
\hline & $\begin{array}{l}\text { Extremely } \\
\text { ineffective }\end{array}$ & ineffective & $\begin{array}{l}\text { Slightly } \\
\text { effective }\end{array}$ & effective & $\begin{array}{c}\text { Extremely } \\
\text { effective }\end{array}$ & $\begin{array}{l}\text { Don't } \\
\text { know }\end{array}$ & responses \\
\hline $\begin{array}{c}\text { children's } \\
\text { rights }\end{array}$ & $0.0 \%$ & $15.6 \%$ & $65.7 \%$ & $6.3 \%$ & $0.0 \%$ & $12.5 \%$ & 32 \\
\hline $\begin{array}{c}\text { women's } \\
\text { rights }\end{array}$ & $0.0 \%$ & $12.9 \%$ & $67.8 \%$ & $6.5 \%$ & $0.0 \%$ & $12.9 \%$ & 31 \\
\hline $\begin{array}{c}\text { immigrant's } \\
\text { rights }\end{array}$ & $9.4 \%$ & $31.3 \%$ & $46.9 \%$ & $0.0 \%$ & $0.0 \%$ & $12.5 \%$ & 32 \\
\hline $\begin{array}{c}\text { refugees and } \\
\text { asylum } \\
\text { seekers rights }\end{array}$ & $34.4 \%$ & $31.3 \%$ & $25.1 \%$ & $0.0 \%$ & $0.0 \%$ & $9.4 \%$ & 32 \\
\hline $\begin{array}{c}\text { older } \\
\text { people's } \\
\text { rights }\end{array}$ & $3.1 \%$ & $18.8 \%$ & $65.7 \%$ & $0.0 \%$ & $0.0 \%$ & $12.5 \%$ & 32 \\
\hline $\begin{array}{l}\text { persons with } \\
\text { disabilities' } \\
\text { rights }\end{array}$ & $3.1 \%$ & $15.6 \%$ & $65.7 \%$ & $6.3 \%$ & $0.0 \%$ & $9.4 \%$ & 32 \\
\hline $\begin{array}{c}\text { ethnic } \\
\text { minorities } \\
\text { rights }\end{array}$ & $12.5 \%$ & $25.0 \%$ & $43.8 \%$ & $0.0 \%$ & $0.0 \%$ & $18.8 \%$ & 32 \\
\hline $\begin{array}{c}\text { indigenous } \\
\text { rights }\end{array}$ & $18.8 \%$ & $34.4 \%$ & $37.5 \%$ & $0.0 \%$ & $0.0 \%$ & $9.4 \%$ & 32 \\
\hline
\end{tabular}

On the other hand, the survey shows that the most effective part of the 2004 NHRAP is concerned with women's rights (Table 2). This result is further strengthened by 2005 Human Development Report in which Australia was ranked second in the world on the Gender-related Development Index (GDI) which measures inequalities between men and women in terms of living a long and healthy life, being educated and having a decent standard of living. ${ }^{38}$ On the Gender Empowerment Measure (GEM), which focuses on women's participation in economic and political life, also, Australia was ranked seventh in $2005 .^{39}$ 
The main focus of this part of the plan is on the 'Beijing Plus Five Action Plan'. In 2000, the Commonwealth Office of the Status of Women developed Australia's Beijing Plus Five Action Plan 2001-2005, as a separate rights-specific NHRAP, to take forward various initiatives fitted inside the larger internationally agreed framework. It is of particular importance as it somehow stepped away from the traditional state-centric concept of planning and was not entirely left upon to the state to decide on its form and substance. ${ }^{40}$ Instead, it was grounded in an internationally agreed conceptual framework i.e. the 'Plat Form for Action' as an international agenda for women empowerment.

This rights-specific action plan was well-structured. Overall, twelve 'critical areas of concern' were identified through the Implementation of the Beijin Platform for Action at the international level beforehand. These included women and poverty, education and training of women, women and health, violence against women, women and armed conflict, women and the economy, women in power and decision-making, institutional mechanisms for the advancement of women, human rights of women, women and the media, women and the environment, and the girl child. ${ }^{41}$

Each 'critical area' encompassed some 'strategic objectives'. For example, in terms of 'education and training of women', six strategic objectives were identified in advance, including:

1. To ensure equal access to education

2. To eradicate illiteracy among women

3. To improve women's access to vocational training, science and technology, and continuing education.

4. To develop non-discriminatory education and training.

5. To allocate sufficient resources for and monitor the implementation of educational reforms.

6. To promote life-long education and training for girls and women. ${ }^{42}$

Each strategic objective, then, was divided into some sub-objectives. For example, as for the first strategic objective with regard to 'education and training of women' i.e. 'ensure equal access to education', the plan set out ten sub-strategic objectives, including: school education, family and life education in schools, civic education, research, vocational education and training, higher education, financial assistance for students, young women at risk, education and training for unemployed people, and literacy. 
Then, as the next subordinate level, 'actions to be taken by governments' were set for each substrategic objective. ${ }^{43}$ For example, as for the 'ensure equal access to education', a set of general measures were identified. Each state, for instance, was required to 'advance the goal of equal access to education by taking measures to eliminate discrimination in education at all levels on the basis of gender, race, language, religion, national origin, age or disability, or any other form of discrimination and, as appropriate, consider establishing procedures to address grievances. ${ }^{44}$

Afterwards, this was government who was called upon to take specific concrete steps in accordance with each country's circumstances and in the line with each strategic objective. As a result, for each sub-strategic objective, one or more new and/or ongoing initiatives were set out by Australian government.

Another important feature of this plan that perhaps had an important impact on its effectiveness was that this action plan was based on a 'social coalitions approach', which refers to coalition with key stakeholders i.e. Commonwealth, State and Territory agencies, women's groups, business sector, the media, community groups and academia. ${ }^{45}$

All this indicates that the Australia's Beijing Plus Five Action Plan 2001-2005 stands somewhere close to the modern understanding of planning. As the statistics show, progress, more or less, can be observed in almost all the 'critical areas'. ${ }^{46}$ Between 2002 (before the plan) and 2012 (after the plan), for instance, the proportion of women, aged 20-24 years, with a Year 12 or Certificate III qualification, increased from 80 percent $(541,800)$ to 86 percent $(693,200)$ in Australia. ${ }^{47}$ Likewise, the proportion of women, aged 25-64 years, with a vocational or higher education qualification, increased significantly more than men, aged 25-64 years, with a vocational or higher education qualification, with the proportion of women increasing from 50 percent $(2.5$ million) in 2002 (before the plan) to 65 percent (3.8 million) in 2012 (after the plan). ${ }^{48}$ In the ten years to 2011, life expectancy at birth, as an internationally recognised indicator of population health, has also improved by 1.8 years for women. ${ }^{49}$ Based on current mortality rates, in Australia, a female born in 2010-2011 can expect to live 84.2 years. ${ }^{50}$ Likewise, for Australian women the annual average unemployment rate $^{51}$ decreased from 6.2 percent in 2002 , to 5.3 percent, in $2012 .^{52}$ 
Overall, Table 2 illustrates that the first two of Australia's NHRAPs were 'slightly effective' in implementing human rights. Statistically speaking, it is interesting to note that in all types of rights, 'slightly effective' is the modal category- except with respect to refugees and asylum seekers rights, the modal category of which is 'ineffective'.

\section{Fundamental Problems}

Survey participants, who were experts in the area of NHRAPs, were asked about the most inhibiting factors in implementing Australia's NHRAP. As the results show, the lack of political will (75.8 percent), lack of public awareness (72.70 percent) and lack of legitimacy among people (60.60 percent) are the most important factors in the way of an effective NHRAP in Australia. Apart from these general factors, the low level of effectiveness of these plans is attributable to some significant problems which stem, inter alia, from the traditional concept of planning upon which the Australia's NHRAPs are based. At the top of the list, there are six fundamental problems including:

1. Top-down state-centric planning

2. Lack of a theoretical foundation

3. Selectiveness

4. Supporting the status quo

5. Ideological orientation

6. Lack of a firm legal status

1. Top down state-centric planning: 50 percent of survey respondents reported that the process of developing the first two NHRAPs in Australia is "top-down" and this is the State that has the strong role in preparing NHRAPs. Only 36.4 percent of participants found it a 'top-down bottom-up' planning and no one marked it as a 'bottom up' planning. Also, there was a clear consensus among the respondents (100 percent) that "Government" has primary responsibility for preparing NHRAPs and that there was "little or no responsibility" for "the public" (57 percent of respondents). 
More specifically, the first NHRAP (1993-1994) was prepared nearly without any consultation with members of civil society, the public and even States or Territories or Federal Parliament. There was likewise no attempt to compile a baseline study or other status report for this plan. ${ }^{53}$ There was also no opportunity for input by the general public. ${ }^{54}$ Being top-down state- centric is a clear element of the traditional model of planning.

Similarly, the second NHRAP (2004) was prepared following very little consultation, with only select non-government organizations being invited to comment in very short time frames. ${ }^{55} \mathrm{In}$ fact, the membership of the steering committee was controlled and staffed by the government without any non-government representatives such as NGO peak bodies ${ }^{56}$ other expert NGOs, representatives of vulnerable groups, trade unions, human rights educators and other community. ${ }^{57}$ As Bill Barker explains:

Despite numerous requests from the NGO community for consultation, officials from the Department of Foreign Affairs and Trade and the AttorneyGeneral's Department persisted in stating that the plan was not yet ready for discussion outside government. Finally, in June 2004, a close-to-final draft was distributed in a single hard copy to each of those NGOs that were in a consultative relationship with either the Department of Foreign Affairs and Trade or the Attorney-General's Department. NGOs were given three weeks to provide comment on a 98-page text. By this stage, interest among NGOs in the process had largely dissipated but those who responded were generally strongly critical, both of the process and the product. ${ }^{58}$

Survey participants were likewise asked about the effectiveness of the 2004 NHRAP in the promotion of coordination of human rights activity among government agencies and NGOs. As the result indicates 6.1 percent of respondents believed that it was 'extremely ineffective' and 24.2 percent felt that it was 'ineffective'. On the other hand, 48.4 percent of survey participants found it 'slightly effective' but no one believed that it was either 'effective' or 'extremely effective'. Of respondents, 21.2 percent of respondents were also 'not sure'.

As all the evidence indicate, there is no question that the first two NHRAPs were based on the traditional understanding of planning and thus only reflected the 'government's approach' to 
improving human rights in Australia. As the second NHRAP (2004) declares 'this Framework for Human Rights - National Action Plan sets out the Australian Government's approach to improving the awareness and enjoyment of human rights in Australia... ${ }^{59}$

2. Lack of a theoretical foundation: Apart from the low level of NGOs participation in preparing and implementing and evaluating NHRAPs, being theoretically groundless, as another characteristic of the traditional understanding of planning can be seen in the Australia's NHRAPs. This point was also confirmed by the online survey. Survey respondents were asked whether there is any particular theoretical base (such as a human rights-based approach to development) for developing NHRAPs in Australia. 71.8 percent of respondents either 'did not know' or believed that there was no theoretical base for developing NHRAPs in Australia. Only 28.1 percent of respondents thought that there was a particular theoretical ground for NHRAPs in Australia. This group of respondents, however, could not specify any particular theory on which the plans were based. The 'failure to conceptualise the plan' on an internationally accepted theoretical ground is an important reason for the NHRAP's ineffectiveness in implementing human rights as set forth in international human rights instruments. The traditional model of planning simply gives way for delinquent states to replace international human rights standards with their own political ideology. That is why Chris Hartley argues that the 2004 NHRAP 'did not reflect a commitment by the Federal Government to uphold and promote Australia's international human rights obligations. ${ }^{60}$

3. Selectiveness: The 2004 NHRAP has been also criticised of being 'selective'. As Chris Hartley states, this plan has failed to respond to a number of human rights concerns in Australia and thus some human rights problems are simply ignored. ${ }^{61}$ The protection of asylum seekers rights is an example. Given consistent criticism of the government's record on the rights of asylum seekers and refugees and its often fractious relationship with United Nations human rights bodies it is regarded by several commentators as extraordinary that the 2004 NHRAP does not even reflect this human rights issue in its main text. As Bill Barker states the plan's selfsatisfied rhetoric and its failure to deal with many important human rights issues seem to be main reasons behind its ineffectiveness in certain areas. ${ }^{62}$ Being selectiveness is another feature of the traditional understanding of planning which is a state-centric model. 
4. Supporting the status quo: Supporting the status quo is a main feature of the traditional model of planning which can be clearly found in the case of Australia. Surprisingly, there is no acknowledgement in the 1994 plan that human rights violations occur in Australia. ${ }^{63}$ This is also true of the 2004 NHRAP. As remarked before, the 2004 plan consists of two main parts: 'overview' and 'Human Rights in Australia'. Instead of probing human rights issues in Australia, Part 1 was merely focused on reviewing the international human rights system and supporting the status quo in Australia. Under the "Australia's robust system of human rights protections" subtitle, for instance, it declared that:

Australia's existing system for protecting human rights is comprehensive, with requirements essential to such protections established and supported by successive governments. The Australian Government recognises that, at a fundamental level, the promotion and protection of human rights is best achieved through strong and robust democratic institutions such as an independent judiciary, responsible and accountable government, the rule of law, well-resourced and respected opposition parties, and a free media. ${ }^{64}$

Similarly, in its Part 2 which is the last part before Annexures, rather than addressing the most pressing issues affecting human rights in Australia, the 2004 action plan, either reviewed some existing human rights policies or sought to justify some current laws and policies which are not necessarily compatible with international human rights standards such as the Shared Responsibility Agreements.

5. Ideological Orientation: Another critical weakness in Australia's NHRAP is that it is coloured by the ideology of the party in power. This is likewise a result of the traditional understanding of planning which is top down state-centric. For example, the 'Shared Responsibility Agreements' (SRA) upon which the 'indigenous rights' part of the 2004 plan is based, is clearly based on the Howard's conservative government's general move away from a rights-based agenda in Aboriginal and Torres Strait Islander affairs to one based on 'practical reconciliation' or obligation-based approach. ${ }^{65}$ As UN special Rapporteur states: 
The Liberal Party of Prime Minister John Howard came to power in 1996 on the basis of a programme under which the Aboriginal question would be given secondary importance and drastic measures in relation to immigration and asylum-seekers would be proposed. ${ }^{66}$

As Bill Barker puts it, a NHRAP should not be structured so that it is seen as reflecting the policies of one political party. ${ }^{67} \mathrm{He}$ further argues that given the universality of human rights a NHRAP should not reflect the policies of one political party and should be able to survive a change of government. ${ }^{68}$

To avoid building NHRAPs castles on ideological quicksand requires an internationally agreed theory upon which these plans can be based. The modern concept of planning will let international human rights law establish an internationally agreed theory such as the human rights-based approach to development, to guide the process and content of NHRAPs. ${ }^{69}$

6. Lack of a firm legal status: As Bill Barker explained in the interview, conducted in this research, the first two Australian NHRAPs only had the status of a government policy - i.e. no legal status as such. ${ }^{70} 51.5$ percent of online survey respondents, who are experts on NHRAPs, believed that the lack of a firm legal status is an inhibiting factor in the effectiveness of Australia's NHRAPs. Although lack of a firm legal status is not a direct outcome of traditional planning, such problems are more likely to be found within a state-centric non-participatory framework of planning.

\section{Subordinate Problems}

In addition to these fundamental problems, at the next subordinate level, four additional problems can be observed in the 2004 NHRAP, including:

1. Lack of a Baseline study

2. Lack of clear target and timeframe

3. Lack of new initiatives 


\section{Lack of monitoring and evaluation mechanisms}

1. Lack of a Baseline Study: The development of the second NHRAP (as with the first one) was not informed by any Baseline Study and did not include a review of the first plan. ${ }^{71}$ This is a result of the traditional planning. To develop a baseline study requires 'criteria', that is, the diagnosis of the current problems depends on an image of the desired state which acts as a point

of reference. ${ }^{72}$ This image comes from a firm theoretical framework upon which planning is based. However, the traditional model of planning is theoretically baseless.

2. Lack of clear target and timeframe: Australia's NHRAPs have been criticised as they did not incorporate any clear target and timeframe. It goes without saying that when targets and time frames are clearly included, it can contribute to the effectiveness of the plan. Given the fact that targets are primarily set out on the basis of a theoretical framework upon which planning is based, this problem can be seen as another outcome of traditional planning which is theoretically baseless.

3. Lack of new initiative: The absence of specific proposals for future action is another objection of these plans which stems from the traditional model of planning upon which the plans are grounded. This problem is closely tied to the problem of supporting the status quo as a major feature of traditional planning. Strikingly, the first plan failed to include any new initiatives that were not already part of existing policies. Likewise, there is nearly no new initiative in the 2004 plan to improve human rights situation in Australia. This is to the extent that the Human Rights Law Resource Centre goes on to state that:

At no point did the 2004 action plan set out any proposals for change. An action plan of this nature serves merely to serve as a cover for human rights failures and undermines the very purpose and aim of an action plan that is conceived and executed in good faith. ${ }^{73}$

In this regard, Chris Hartley argues that while the 2004 action plan emphasised Australia's commitment to human rights and international law, it failed to include any active measures that would lead to a greater realisation of rights. ${ }^{74}$ In the same vein, Bill Barker explains that 'the plan focuses heavily on describing existing programs. To the extent that it provides for future action, it usually refers to ongoing programs that do not owe their existence to the plan.' 75 
4. Lack of monitoring and evaluation mechanisms: No mechanism could be found for monitoring and evaluation of the first two NHRAPs. In this regard, online survey participants were asked whether there is any specific mechanism for monitoring (i.e. assessing ongoing plan processes) NHRAPs in Australia? The majority of respondents (74.2 percent) answered "no" or "not sure". Only 8 (out of 33) respondents said "yes", though they could not specify any. They were also asked about evaluation mechanisms for assessing the plan as a whole and the results achieved. Again, the majority of respondents ( 84.4 percent) said "no" or "not sure". It was merely 5 respondents (15.6 percent) who thought there was an evaluating mechanism for Australia's NHRAP. Of this number, two respondents believed that Attorney General will review the result achieved.

Lack of monitoring and evaluation mechanisms is another outcome of the traditional concept of planning which is theory neutral. To develop different mechanisms for monitoring and evaluating any plans, including NHRAPs, requires criteria which stem from a theory which is absent in traditional planning. Alexander notes that 'for normative activities like planning, theory is not only important for developing but also necessary for evaluation. ${ }^{76}$

\section{B. Australia's Current NHRAP}

The online survey respondents were asked that 'how effective will the implementation of the new NHRAP (2012) be in realising different types of rights?' Among various rights, respondents marked women's rights and children's rights as the most effective parts of the plan (Table 3). It is worth noting that the women's rights part of the 2012 NHRAP mostly refers to another rightsspecific NHRAP, known as the 'National Plan to Reduce Violence against Women and their Children 2010-22' (NPRVWC). This is also true of the children's rights part of the plan which is mainly based on another rights-specific NHRAP, entitled 'National Framework for Protecting Australia's Children' (NFPAC). It is striking that these two rights-specific action plans stand close to the modern model of planning and are based on four main features: First, these plans are evidence-based. Second, unlike most of the existing NHRAPs, these plans, in particular the NFPAC, are grounded in a 'theoretical model'- a considerable feature of the NFPAC is that it promotes a 'public health model' approach to child protection. As Daryl Higgins puts it, one of 
the most important characteristics of the NFPAC is 'the shift to seeing-or at least explicitly recognising - the protection of children as a public health issue; one that goes well beyond statutory systems. ${ }^{, 77}$ Third, Australia in relation to women's rights and children's rights has adopted an 'integrated governance approach" ${ }^{78}$. According to the Progress Report to the Council of Australian Governments (2010-2012), the integrated governance approach as a new way of engagement leverages the valuable experiences and expertise of different groups. This approach cuts across government boundaries and moves away from the traditional 'single agency' approach and includes the non-government sectors in order to plan and implement actions. Australia's current NHRAP in the areas of women and children has included an unprecedented level of collaboration between Australian, State and Territory governments and non-government organisations. Within this approach in the experience of Australia, different groups serve different purposes. Some perform a high-level oversight role in tracking the progress of the plan and change its direction if necessary. Others are directly involved in the day-to-day management of certain actions. Some also focus on engaging with external groups. On the top of this, key stakeholders are kept involved through ongoing consultation. Fourth, these two plans are based on vast knowledge of experts from 'top down' and detailed local wisdom of communities from 'bottom up'.

On the contrary, the least effective parts of the 2012 NHRAP are concerned with the refugees and asylum seekers rights and indigenous rights respectively (Table 2). These parts of the plan are based on the very nature of the traditional model of planning. For instance, while treaty bodies and the Human Rights Council in the context of the UPR have called for an end to mandatory detention in Australia, ${ }^{79}$ the Government in its current NHRAP, as with the first two plans, explicitly supports 'mandatory detention' and declares that: 'the Australian Government believes mandatory detention is an essential component of strong border control. ${ }^{, 80}$ 
Table 3: Online survey participants' views on the effectiveness of the 2012 NHRAP in implementing human rights

\begin{tabular}{|c|c|c|c|c|c|c|c|}
\hline & $\begin{array}{l}\text { Extremely } \\
\text { ineffective }\end{array}$ & ineffective & $\begin{array}{l}\text { Slightly } \\
\text { effective }\end{array}$ & effective & $\begin{array}{l}\text { Extremely } \\
\text { effective }\end{array}$ & $\begin{array}{l}\text { Don't } \\
\text { know }\end{array}$ & Responses \\
\hline $\begin{array}{c}\text { children's } \\
\text { rights }\end{array}$ & $3.3 \%$ & $13.3 \%$ & $70.0 \%$ & $10.0 \%$ & $0.0 \%$ & $3.3 \%$ & 30 \\
\hline $\begin{array}{c}\text { women's } \\
\text { rights }\end{array}$ & $3.4 \%$ & $10.3 \%$ & $75.9 \%$ & $3.4 \%$ & $0.0 \%$ & $6.9 \%$ & 29 \\
\hline $\begin{array}{c}\text { immigrant's } \\
\text { rights }\end{array}$ & $6.7 \%$ & $30.0 \%$ & $60.0 \%$ & $0.0 \%$ & $0.0 \%$ & $12.5 \%$ & 30 \\
\hline $\begin{array}{l}\text { refugees and } \\
\text { asylum } \\
\text { seekers rights }\end{array}$ & $36.7 \%$ & $23.3 \%$ & $36.7 \%$ & $0.0 \%$ & $0.0 \%$ & $9.4 \%$ & 30 \\
\hline $\begin{array}{c}\text { older } \\
\text { people's } \\
\text { rights }\end{array}$ & $7.1 \%$ & $21.4 \%$ & $57.2 \%$ & $10.7 \%$ & $0.0 \%$ & $12.5 \%$ & 28 \\
\hline $\begin{array}{l}\text { persons with } \\
\text { disabilities' } \\
\text { rights }\end{array}$ & $6.7 \%$ & $13.3 \%$ & $60.0 \%$ & $13.3 \%$ & $3.3 \%$ & $9.4 \%$ & 30 \\
\hline $\begin{array}{c}\text { ethnic } \\
\text { minorities } \\
\text { rights }\end{array}$ & $13.3 \%$ & $10.0 \%$ & $63.3 \%$ & $3.3 \%$ & $0.0 \%$ & $18.8 \%$ & 30 \\
\hline $\begin{array}{c}\text { indigenous } \\
\text { rights }\end{array}$ & $17.2 \%$ & $31.0 \%$ & $44.8 \%$ & $3.4 \%$ & $0.0 \%$ & $9.4 \%$ & 29 \\
\hline
\end{tabular}

This attitude is consistent with a very aggressive increase in immigration detention. ${ }^{81}$ As reported by the Department of Immigration and Border Protection, the number of people in immigration detention, who arrived unlawfully by air or boat as at 30 November 2013 was $9016^{82}$ This represents about 96 percent of the total immigration detention population. There were also 415 people (about 4 percent of the total immigration population) who arrived in Australia lawfully 
and were subsequently taken into immigration detention for either overstaying or breaching their visa conditions, resulting in visa cancellations. ${ }^{83}$ The average period of people held in detention facilities, first, decreased from 277 days in November 2011 to 83 days in September 2012 (before the plan), but, again, it increased to 176 days as at 30 November 2013 (after the plan). ${ }^{84}$

Although the 2012 NHRAP, further, included that 'it [Australian government] also remains committed to ensuring detention is not indefinite or arbitrary and providing health and other supports for asylum seekers in detention', ${ }^{85}$ the UN Human Rights Committee, reported that Australia has breached the ICCPR by indefinitely detaining refugees. ${ }^{86}$ It asserted that Australia has violated Articles 7 and 9 of the Convention through detaining refugees arbitrarily, failing to provide an effective judicial remedy and subjecting detainees to conditions of detention which are 'cumulatively inflicting serious psychological harm upon them' ${ }^{87}$ The Committee directed the Australian Government to provide all refugees in this situation with an effective remedy, including release from detention under appropriate conditions, rehabilitation and appropriate compensation. ${ }^{88}$

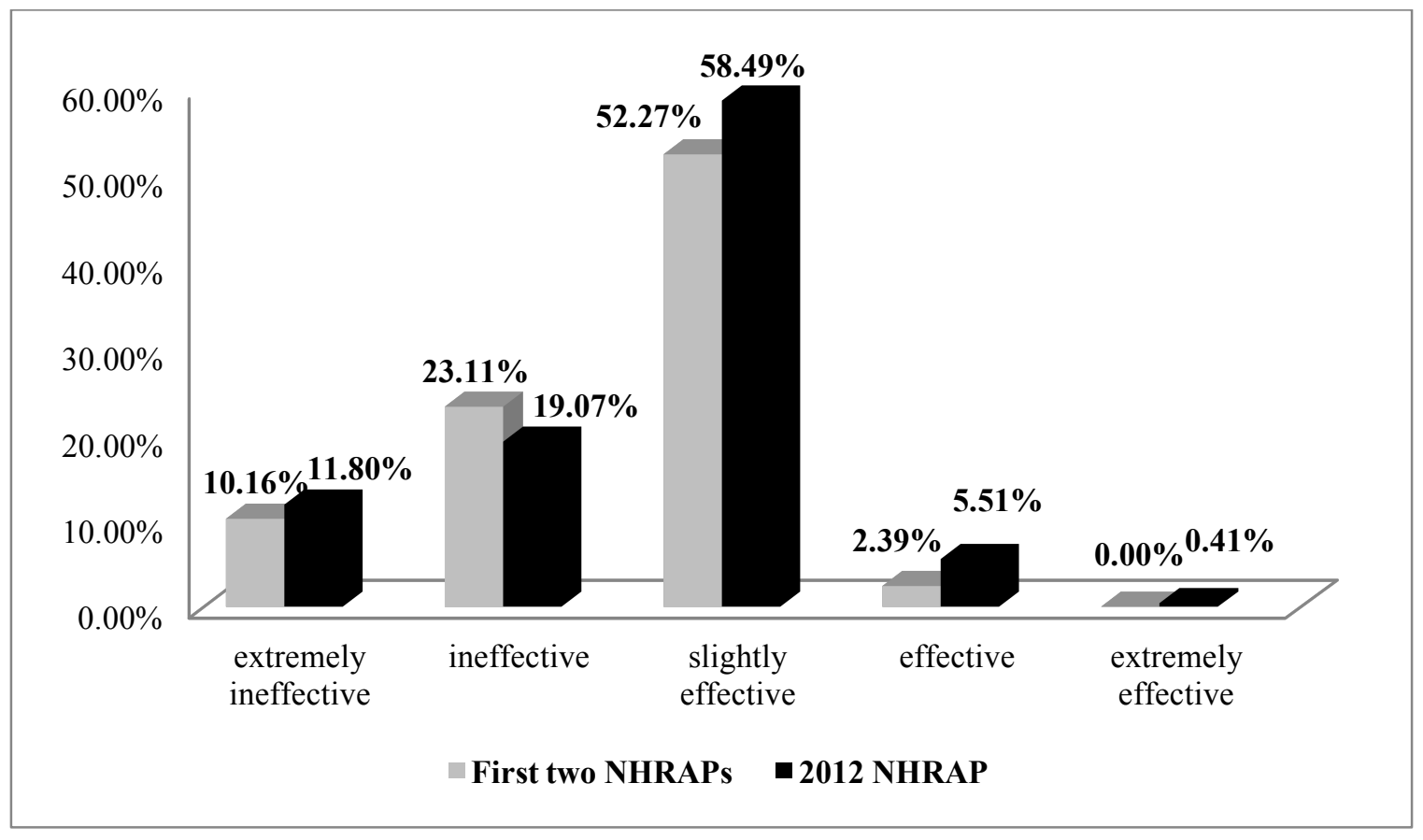

Figure 1: Histogram of online survey experts' assessment of the effectiveness of Australia's NHRAPs 
Overall, the level of effectiveness of NHRAPs in implementing human rights has improved in the current NHRAP. The relative improvement of the current NHRAP compared with the first two NHRAPs can be seen in Figure 1. This improvement is, at least partly, because of the fact that the new plan steps away from the very nature of traditional planning.

\section{Enhancing Factors}

As an open-ended question, survey participants were asked about what they like best about the current Australia's NHRAP (2012). They mentioned different factors which contributed to the effectiveness of the current NHRAP. These factors which all can be seen in a modern model of planning, include:

1. consultation with NGOs,

2. developing a Baselines Study

3. linkage to the UPR

4. clear time-frames.

Consultation with NGOs: In contrast with the first two NHRAPs, the third/current plan (2012) was developed in 'consultation' with the public, particularly non-government organisations. 63 percent of the survey respondents believed that NGOs have had "some responsibility" for preparing NHRAPs in Australia. As part of the preparatory phase of the third Australia's NHRAP, in June 2011, the government released a Baseline Study and asked the public and NGOs for their comments and feedbacks. Almost 50 submissions, mostly from nongovernmental organizations, were received by the Attorney-General's Department. This generated a great deal of public and media attention and played a part in raising awareness of such plans. ${ }^{89}$ As stated by the Australian Government, the submissions received contributed to the Government's understanding of the human rights concerns of the community. However, there was no guarantee that the comments made in the submissions are to be taken into considerations by the Government. In this regard, survey respondents were asked that to what extent they feel that the 2012 NHRAP has been developed in consultation with the public, particularly NGOs. Only 18.8 percent ( 6 out of 32 ) of respondents answered 'to a large extent'. 40 percent of them felt 'to a moderate extent' and 28.1 percent also answered 'to a small extent' or 'extremely small 
extent'. This moderate level of consultation should be distinguished from a 'meaningful involvement' in which NGOs are genuinely involved in the process of decision making,

Although NGOs consultation should not be degraded at any rate, a distinction can perhaps be made between 'consultation' and 'participation'. Whereas in community participation, the public and NGOs play an active part and have a significant degree of power and influence in decision making and planning, in consultation, they are not genuinely involved in the process of decision making and no mechanism is in place to guarantee that their views will be taken into account by government. And this is what can render all the submissions ineffective.

Moving on from the 'development phase', moreover, it should be noted that the public and NGOs have not been involved, even in the form of 'consultation' in the 'implementation phase' of the NHRAP in Australia.

Developing a Baseline Study: To develop the third Australian NHRAP, unlike the previous action plans, the Federal Government proposed to undertake a Baseline Study to examine where Australia stands in terms of human rights situation. A Draft Baseline Study was accordingly released for comment on 8 July 2011. As Bill Barker argues there is no doubt that this is a very positive move forward and in many cases the consultation itself has been of value in raising awareness of human rights, legitimising human rights as a subject of discussion and putting human rights on the national agenda, regardless of the plan outcomes. ${ }^{90}$ However there are a number of pitfalls in this Baseline Study that will be identified as follows:

Firstly, there is no guarantee that comments made on the Baseline Study will be considered by the government. As Sarah Joseph and Adam Fletcher argue:

Strong and robust' they [comments] may be, but even formal recommendations by the Parliamentary Committees or the Australian Human Rights Commission (AHRC) are at best persuasive, and can be ignored if the Government of the day declines to accept them. This should be acknowledged as a significant protection gap. $^{91}$

Secondly, supporting the status quo is a major feature of the Baseline Study which stems from the traditional planning. As reported by the Women's Legal Centre (WLC), there is a 'biased 
presentation' ('selectiveness') in the Baseline Study. ${ }^{92}$ Similarly, Joseph and Fletcher conclude that:

[T] he Baseline Study needs to strike a better balance between exposition of existing policies and laws and acknowledgement of gaps in protection. It should be seen as conceptually distinct from, for example, periodic reports to the United Nations treaty bodies, which by their nature tend to defend Australia's human rights record and explain Government policy to the external experts. The Baseline Study is a reference document for domestic actors who are generally familiar with the issues and policies, and to be useful it must confront the gaps in the protection and realisation of human rights in Australia in an open manner. ${ }^{93}$

The Human Rights Law Centre considers that the Baseline Study highlights numerous positive examples of initiatives and developments in particular States and Territories but it fails to identify the problems, deficiencies or "gaps". ${ }^{94}$

Thirdly, the same as the previous plans, this baseline study and following that the current plan itself is highly selective in that, in many cases, it fails to incorporate relevant human rights recommendations, made at the national and/or international level, even where the recommendations have been reiterated. For example, in the National Human Rights Consultation, 'the most contested option for better protection and promotion of human rights was the introduction of comprehensive legislative protection, variously referred to as a 'bill of rights', a 'charter of rights' or a 'human rights Act'. Of the 35014 submissions received for the consultation, 32091 discussed the option of a charter of rights or a human rights Act. Of these, 27888 were in favour and 4203 were opposed'. ${ }^{95}$ The National Consultation, therefore, in recommendation 18 (out of 31 recommendations) unequivocally stated that 'Australia adopt a federal Human Rights Act'. Before that, the ICCPR Committee also recommended the Australian Government to adopt a Human Rights Act or similar legislation. ${ }^{96}$ Despite all these recommendations, made at the national and international levels, however, neither the Baseline Study nor the NHRAP makes any reference to this critical human rights issue. This can be seen as a result of the traditional understanding of planning. 
Linkage to the UPR: Another factor in the effectiveness of the current NHRAP, highlighted in the survey, is its linkage to the UPR's recommendations. The Australian Government accepted almost 95 per cent of the Council's recommendations made in its first UPR and committed to using them to inform the development of Australia's new NHRAP. In the words of the current NHRAP:

Consequently, the Action Plan demonstrates how Australia is turning the commitments made at the UPR into specific actions to improve and promote human rights. All UPR recommendations accepted or accepted-in- part by Australia are referenced against specific measures in the Action Plan. ${ }^{97}$

Undoubtedly, this was a promising step towards incorporating the international community's human rights concerns into domestic planning. ${ }^{98}$ As Anna Brown puts it 'the NHRAP helps Australia move from "talking the talk" to "walking the walk" when it comes to implementing commitments made during Australia's Universal Periodic Review by the UN Human Rights Council. $^{99}$

Nonetheless, references to the UPR recommendations throughout the plan are often cursory or partial. ${ }^{100}$ There is a list of the recommendations that Australia accepted but to which the plan makes no reference. ${ }^{101}$ Additionally, a number of UPR recommendations, accepted by the Australian Government, are broadly addressed but not explicitly referred to in the plan. ${ }^{102}$

Apart from this, the Australian Government also failed to observe the other human rights treaties and instruments to which it is a signatory in its NHRAP such as the United Nations Declaration on the Rights of Indigenous Peoples (UNDRIP). As Joseph and Fletcher argue 'the UPR process is undeniably important, but the treaty bodies comprise experts in human rights law who (generally) make targeted, detailed and well-informed recommendations which are just as (if not more) important to consider in the development of the Action Plan.' 103

Clear time-frames: One of the positive aspects of the current NHRAP is that for each action, it has included relatively clear timeline which is a characteristic of the modern model of planning. For example, 'Australian Government funding for the Reconciliation Australia led community awareness initiative covers a two year period, ending 30 June 2014. ${ }^{104}$ However, it is not always clear enough; for many 'Actions', the timeline is simply marked as 'ongoing'. ${ }^{105}$ 


\section{Inhibiting Factors}

While Australia's third NHRAP (2012) represents a commendable list of 355 actions, it still falls short of international best practice in a number of respects. As for the above-mentioned fundamental problems, 'selectiveness', 'supporting the status quo' and 'ideological orientation' can be found in this NHRAP. This plan also does not enjoy a firm legal status. It has not been put before parliament, though if implementation of a specific part of it required legislation, appropriate action would be taken. ${ }^{106}$ This means that it can be changed or ignored by an incoming government. ${ }^{107}$ As far as the four subordinate problems are concerned, two of them i.e. the lack of a baseline study and lack of clear time frames have been addressed in the current NHRAP. Nonetheless, the lack of new initiatives still remains. There is also nothing about evaluating the plan. Likewise, the monitoring section of the current plan is more like a mere 'label'. Under the title 'monitoring', in the last section of the plan which is less than a half page, it vaguely states that 'the Australian Government Attorney-General's Department will monitor overall implementation of the Action Plan.' As remarked before, the Government, in the final version of the plan, removed the modest commitment to develop a suite of human rights indicators in favour of a limited pilot project. Without a firm mechanism for monitoring and

evaluation, the NHRAP runs the risk of stalling without any substantive results. ${ }^{108}$ All this can be a result of the traditional model of planning upon which the current NHRAP is based. In addition to these problems, three minor defects can also be observed in the current NHRAP. These include:

1. Lack of a review of the previous plans

2. Removing original actions from the final version

3. Promising talk rather than real action

1. Lack of a review of the previous plans: Survey respondents were asked that 'to what extent do you think that the new plan is based on the overall evaluation of the previous NHRAPs in Australia?' 25.8 percent of them answered 'to a moderate extent' and 41.9 percent said 'to a 
small extent' or 'extremely small extent'. It is unfortunate that the majority of respondents either was 'not sure' or felt that the current NHRAP is only based on the overall evaluation of the previous Australia's NHRAPs 'to a small extent'.

2. Removing original actions from the final version: In December 2011, the Australian Government released a draft of the new NHRAP and sought submissions into the content of the exposure draft. Following all the comments and recommendations made on the Baseline Study and the exposure draft, eventually, on 10 December 2012, the Australian Government released the final version of the third NHRAP. This version has been updated to include developments since the exposure draft was released, highlighting a number of human rights achievements in 2012 , however, as scrutinized by the Human Rights Law Centre, surprisingly, a number of 'actions' set in the exposure draft were also removed from the final version of the NHRAP. ${ }^{109}$ This is a result of the traditional concept of planning which is top-down state-centric.

3. Promising talk rather than real action: under the title of 'Action', the plan sometimes simply uses 'promise to consider further' (and not 'promise to change') such as 'will review' rather than 'real action'. For example, it states that 'the Australian Government will $\underline{\text { review }}$ its reservations under the following international human rights instruments...'. NHRAPs are the place of actions. All the 'reviews' possibly could to be done in the 'preparatory phase', through the Baseline Study. In a similar vein, the 2012 NHRAP includes a considerable number of 'actions' which include only 'considering something by government' rather than a 'specific clear action'. ${ }^{110}$

\section{Conclusion}

This mixed methods study sought to show that among other factors, the traditional concept of planning, which has been widely under-noticed by both academics and practitioners, could generate at least two sets of problems in the way of an effective action plan for implementing human rights in Australia. At the top of the list, there are six fundamental problems. These include: top-down planning, lack of a theoretical foundation, selectiveness, supporting the status quo, ideological orientation, and lack of a firm legal status. At the next subordinate level, there are four additional problems including the lack of a Baseline Study, lack of clear target and time 
frames, lack of new initiatives and lack of monitoring and evaluation mechanisms. Traditional planning can also reinforce other causal factors i.e. the lack of political will, lack of legitimacy among people and lack of public awareness, through four mechanisms:

1. Traditional model of planning as a mirror image of central planning of the former Soviet Union can discourage political elites and those who are in power to adopt a NHRAP and thereby intensify the lack of political will to use planning for implementing human rights. Put differently, a distinction could be made between the lack of political will to implement human rights and the lack of political will to use planning for the implementation of human rights. While the former seems to be an issue of many countries and can be found mostly in authoritarian regimes, the latter would be a concern of mostly democratic (liberal) nations where planning, in its traditional form, reminds political elites of central planning used in the former Soviet Union where a life plan was imposed, implicitly or explicitly, on people by those in authority from top down and thus limited notably human freedom.

2. The above-mentioned mechanism similarly can reduce the legitimacy of planning among the public and lessen public support for NHRAPs.

3. Traditional planning, by its very nature, can restrict public participation and impose constraints on public awareness of these plans.

4. Traditional planning, as a theory-neutral model, is like an empty box which confers power upon the States to fill it up with their own ideologies and particular values ranging from fascism to liberalism. In a positive case like Australia which has a democratic political system and enjoys a positive human rights record, this model of planning has been 'slightly effective'. In other cases, it would be, thus, hardly surprising, if these plans were simply developed for the sake of doing or for appeasing international pressure on human rights.

In contrast with the first two of Australia's NHRAPs, which were based on the very nature of the traditional model of planning, the current Australia's NHRAP has partly come close to the modern model of planning. Some of the above-mentioned problems i.e. the lack of a baseline study and lack of clear time frames completely and top-down state-centric planning partially have been addressed in this recent NHRAP. The current experience of Australia, in particular in the areas of women and children, provides clear lessons for future practices: 
1. Linkage to UPR: One of the important factors that accounts for variation in the effectiveness of the current NHRAP compared to the former plans is its linkage to the UPR. Incorporating UPR into a NHRAP is a new initiative which can be used as a multi-purpose strategy. First, it can be used to persuade and/or force the states to fulfill their obligation to adopt a NHRAP. Second, it can be employed as a way to monitor and evaluate countries' NHRAPs. Third, it can effectively inform the states on the form and substance of their plans. And finally, it can be used to share the best practices of developing or implementing NHRAPs among the states. Hence, it might be plausible to require the states to provide their NHRAP(s) along with their UPR country's report.

2. Developing a Baseline Study: A comprehensive baseline study can enhance the contribution of NHRAP by establishing clear links between past, present and future initiatives and serve at least four purposes. First, it can present a panorama of human rights situation in the country concerned and help government to prioritise problems in accordance with available resources. Second, it can provide opportunities for different stakeholders to get involved in the identification of human rights problems and investigation of solutions. Third, it can offer benchmarks against which progress, if any, can be measured. Fourth, this may provide relevant data for selecting or even formulating and elaborating special theories for the development of each part of a NHRAP.

3. Integrated governance: The most effective parts of the current NHRAP in Australia are related to women's and children's rights and these two parts are based on two rights-specific action plans i.e. National Plan to Reduce Violence against Women and their Children 201022' (NPRVWC) and National Framework for Protecting Australia's Children' (NFPAC) respectively. It is interesting that these two effective plans both have adopted and significantly highlighted what is called the 'integrated/ partnership governance' approach. This mode of governance which seems to have contribution to the successful planning on women's rights and children's rights in Australia goes beyond the traditional government boundaries and replaces the idea of 'hierarchical government'. 
4. Evidences-based: The most effective parts of the Australia's NHRAP (2012) are evidencebased. As for the women's rights part of the plan, for instance, the Australian Government established the National Council to Reduce Violence against Women and their Children and asked it to develop an evidence-based plan based on community consultation, assessing existing Australian and international research, investigating the effectiveness of legal systems and commissioning research on the economic costs of violence. The Council focused on improving and coordinating the evidence base in the areas of domestic violence and sexual assault.

5. Top-down bottom-up strategy: The current Australia's NHRAP was developed in wide consultation with the public and non-governmental organisations. Almost 50 submissions from non-governmental organisations were received by the Attorney-General's Department which all contributed to the Government's understanding of the human rights concerns of the community in Australia. Moreover, this wide consultation generated a great deal of public and media attention and played a part in raising awareness of such plans. More specifically, the experience of Australia in the area of women's rights, as the most effective part of the current plan, is based on community participation. It combines the advantages of expert knowledge from top-down and local wisdom from bottom-up. For example, the Australian National Council to Reduce Violence against Women and their Children consulted with more than 2,000 Australians in every state and territory, conducted expert roundtable discussions, interviewed victims and perpetrators of violence and reviewed more than 350 written submissions.

6. Theoretical foundation: Australia's experience in planning on children's rights moves away from the traditional model of planning and enjoys a theoretical foundation. Unlike most of the existing NHRAPs, developed on the basis of the traditional model of planning, the NFPAC, as one of the most effective parts of the current Australia's NHRAP, is significantly grounded in the 'public health approach'. This approach, as a theoretical foundation, informs the substance of NFPAC which is a rights-specific action plan for children's rights in Australia. 
Taken together, the findings of this study suggest a strategic shift towards the modern model of planning which is multi-level, top-down bottom-up, participatory, evidence-based and theoryladen. A NHRAP, if properly designed and implemented, through an informed and continued demand by and meaningful participation of all the stakeholders, in line with the modern concept of planning, supported by political will and backed by firm legal status can pave the way for human rights-based development. Otherwise, adopting a NHRAP, by itself, would be more like window dressing rather than an effective roadmap to development.

\section{Acknowledgements}

The author owes a deep debt of gratitude to Bill Barker, the author of the UN Handbook on National Human Rights Action Plans, who generously shared his invaluable time, experience and knowledge for the purposes of this research. The author is extremely grateful to the online survey participants who took the time from their busy schedules to participate in this study. Without their participation and feedback, this study would not have been possible.

\section{Note on contributor}

Azadeh Chalabi is a lecturer in Law, School of Law and Transitional Justice Institute, Ulster University. Her main research interests include communities' rights practices, national action plans on business and human rights, national action plans on women, peace and security, and global governance for implementing human rights. All her work is published in peer reviewed journals and the majority appears in the leading journals in the area. She is currently completing a book on National Human Rights Action Plans.

\footnotetext{
Notes

${ }^{1}$ A. Chalabi, 'The Nature and Scope of States' Obligation to Adopt a National Human Rights Action Plan', (2014) a The International Journal of Human Rights. Volume 18, Issue 4-5, 391-413

${ }^{2}$ The Human Development Index (HDI) is a summary measure of average achievement in key dimensions of human development: a long and healthy life, being knowledgeable and have a decent standard of living. The HDI is the geometric mean of normalized indices for each of the three dimensions.

${ }^{3}$ A. Pal, Planning from the Bottom Up: Democratic Decentralization in Action (Amesterdam: IOS Press BV, 2008); P. Cook, Theories of Planning and Spatial Development (London: Hutchinson \& Co, 1983); J. Rothman and M. Hugentobler, 'Planning Theory and Planning Practice: Roles and Attitudes of Planners: A Synthesis of Empirical Research and Formulation of Derived Applications'. In M. J. Dluhy and K. Chen (eds). Interdisciplinary Planning: A Perspective for the Future. (New Jersey: The Center for Urban Policy Research, 1986)

${ }^{4}$ A. Chalabi, 'The Problem Oriented Approach to Improving National Human Rights Action Plans' (2015)The Oxford Journal of Human Rights Practice7 (2): 272-298

${ }^{5}$ A. Faludi,. 'What is Planning Theory'. in A. Faludi (ed). A Reader in Planning Theory (Oxford: Pergamon Press, 1973)
} 
${ }^{6}$ A. Chalabi, "States' Compliance with the Obligation to Adopt a National Human Rights Action Plan" (2015) The European Human Rights Law Review, Issue 4, 395-403; A. Chalabi, 'The Problem Oriented Approach to Improving National Human Rights Action Plans' (2015)The Oxford Journal of Human Rights Practice7 (2): 272-298

${ }^{7}$ J. Friedmann, Insurgencies: Essays in Planning Theory (London: Routledge, 2011) 15

${ }^{8}$ W.L. Schonwandt, Planning in Crisis? Theoretical orientation for Architecture and Planning (London: Ashgate, 2008) 5

${ }^{9}$ E.R. Alexander, Approaches to Planning: Introducing current Planning Theories, Concepts and Issues, (Luxembourg: Gordon and Breach Publishers, 1995) 102; M.J. Thomas, 'The Procedural Planning Theory of A. Faludi'. In C. Paris (ed). Critical Readings in Planning Theory (Oxford: Pergamon Press, 1982)

${ }^{10}$ ibid; E. Reade, British Town and Country Planning. London: Open University Press, 1987)

${ }^{11}$ P. Allmendinger, Planning Theory (New York: Palgrave Macmillan, 2009); W.L. Schonwandt, Planning in Crisis? Theoretical orientation for Architecture and Planning (London: Ashgate, 2008)

${ }^{12}$ A. Chalabi, 'The Problem Oriented Approach to Improving National Human Rights Action Plans' (2015)The Oxford Journal of Human Rights Practice7 (2): 272-298

${ }^{13}$ See J. Ife, Human Rights from Below: Achieving Rights through Community Development. Cambridge: Cambridge University Press, 2009)

${ }^{14}$ See F. Westley, 'Governing Design: The Management of Social Systems and Eco-systems Design'. In L.H. Gunderson C. S. Holling and S.S. Light (eds), Barriers and Bridges to the Renewal to Ecosystems and Institutions. (Columbia: Columbia University Press, 1995); J. Friedmann, ‘Towards a Non-Eucidian Mode of Planning'. In S.Campbell and S. S. Fainstein (eds) Readings in Planning Theory (Oxford: Blackwell Publishing, 2003); P. Healeyet, et al., Planning Theory: Prospects for the 1990s (London: Ashgate, 1991); B.M. Hudson, "Comparative and Current Planning Theories: Counterparts and Contradictions" (1979) 45(4) JAPA 387; N. Taylor, 'Planning Theory and the Philosophy of Planning'. Urban Studies. (1980) 17(2) 159-172)

${ }^{15}$ N. Harris, 2002. 'Collaborative Plnning : From Theoretical Foundations to Practice Forms', in P. Allmendinger and M. Tewdwr-Jones(eds). Planning Futures New Directions for Planning Theory. London: Routledge

${ }^{16}$ A. Chalabi, "States' Compliance with the Obligation to Adopt a National Human Rights Action Plan" (2015) The European Human Rights Law Review, Issue 4, 395-403; A. Chalabi, 'The Problem Oriented Approach to Improving National Human Rights Action Plans' (2015)The Oxford Journal of Human Rights Practice7 (2): 272-298

${ }^{17} \mathrm{~J}$. Ife, Human Rights from Below: Achieving Rights through Community Development. Cambridge: Cambridge University Press, 2009) 208

${ }^{18}$ A. Chalabi, "States' Compliance with the Obligation to Adopt a National Human Rights Action Plan"

19 A. Pal, Planning from the Bottom Up: Democratic Decentralization in Action (Amesterdam: IOS Press BV, 2008)

${ }^{20}$ Ernest R. Alexander, Approaches to Planning: Introducing current Planning Theories, Concepts and Issues, (Luxembourg: Gordon and Breach Publishers, 1995) 3

${ }^{21}$ ibid

${ }^{22}$ S. Campbell and S. Fainstein, "Introduction: the Structure and Debates of Planning Theory", in Scott Campbell and Susan S. Fainsteineds, Readings in Planning Theory (2nd ed. Oxford: Blackwell Publishing, 2001) 3

${ }^{23}$ A. Chalabi, 'The Problem Oriented Approach to Improving National Human Rights Action Plans'

24 These organizations include, but are not limited to: Act Human Rights Commission (Governmental organization),Anti-discrimination Commission Queensland, Australian federation of disability organizations, Australian Human Rights Centre, Australian Human Rights Commission (Governmental organization), Human Rights Law Centre, Australian Lawyers for Human Rights, Castan Centre for Human Rights Law, Children with Disability Australia, Civil Liberties Australia, Commonwealth Government, Disability Advocacy, Elder Rights Advocacy, Indigenous Research Unit, Leadership Plus, New South Wales Council for Civil Liberties, Victorian Equal Opportunity and Human Rights Commission(governmental Organization), Young people In Nursing Homes National Alliance, Australian National University, Monash University, University of South Australia, University of New South Wales, The University of Queensland, Charles Sturt University.

${ }^{25} \mathrm{~A}$ completed response is when the survey taker reaches the last page of the survey.

${ }^{26}$ Bill Barker, interview, October 2013

${ }^{27}$ Barker, B. 2011. Protecting, Promoting and Fulfilling Human Rights in Australia: A National Human Rights Action, 6

${ }^{28}$ ibid

${ }^{29}$ ibid

${ }^{30}$ Bill Barker, interview, October 2013

${ }^{31}$ ibid, 13 
32 ibid, 14

33 ibid

${ }^{34}$ Australian Government (2004) Australia’s National Human Rights Action Plan, 85. Available at:

http://www.ohchr.org/EN/Issues/PlansActions/Pages/PlansofActionIndex.aspx

${ }^{35}$ See UNHRC 24/07/2000. A/55/40, Sixty-ninth session, paras.498-528; UN Doc CCPR/C/AUS/CO/5 (2009), para 23; UN Doc E/C.12/AUS/CO/4 (2009) para 25; UN Doc A/HRC/14/30/Add.4 (2010) 21-24; UN Doc

E/CN.4/2003/8/Add.2; UN Doc CRC/C/15/Add.268, para 62; UN Doc CCPR/C/76/D/900/1999 (2002), para 8.2; 24/07/2000. A/55/40,paras.498-528, Sixty-ninth session, 3

${ }^{36}$ Human Rights and Equal Opportunity Commission, A last resort? National inquiry into children in immigration detention, Commonwealth of Australia(2004) Available at:

$<\mathrm{http}$ //www.hreoc.gov.au/human_rights/children_detention_report/index.html>accessed on 22 May 2013>

${ }^{37}$ Human Rights and Equal Opportunity Commission Report (2004) 9

${ }^{38}$ Human Development Report (2005) Available at : http://hdr.undp.org/en/content/human-development-report2005

${ }^{39}$ Gender Empowerment Measure (GEM), available at: http://www.nationmaster.com/countryinfo/stats/People/Gender-empowerment-measure

${ }^{40}$ See Anne-Marie Mooney-Cotter, Culture Clash: An International Legal Perspective on Ethnic Discrimination $\left(1^{\text {st }}\right.$ edn, Ashgate, 2011)

41 See Anne-Marie Mooney Cotter, Gender Injustice: An International Comparative Analysis of Equality in Employment ( $1^{\text {st }}$ edn, 2004, Ashgate)

42 The United Nations Fourth World Conference on Women, Platform for Action (1995)

http://www.un.org/womenwatch/daw/beijing/platform/plat1.htm\#objectives> accessed 25 May 2012

${ }^{43}$ ibid

44 ibid

${ }^{45}$ Australian Department of the Prime Minister and Cabinet, Australia's Beijing Plus Five Action Plan 2001-2005 < http://www.dpmc.gov.au/women/publications-articles/government-international/un-4th-world-conference-onwomen/beijing-plus-five-action-plan-2001-05.cfm> accessed 23 May 2013

${ }^{46}$ Australia's response to the UNESCAP Questionnaire on the implementation of the outcome of the Fourth World Conference on Women (Beijing 1995), APRIL 2009

http://www.dss.gov.au/sites/default/files/documents/05_2012/unescap_questionnaire_response.pdf >accessed 23 June 2013

${ }^{47}$ Australian Bureau of Statistics, 2002-2011 Survey of Education and Work

<http://www.abs.gov.au/ausstats/abs@.nsf/Lookup/1370.0main+features292013> accessed 23 May 2013

${ }^{48}$ ibid

${ }^{49}$ Life expectancy is considered a good measure of progress for health because it is one of the most widely used and internationally recognised indicators of population health. It focuses on the length of life rather than its quality, but provides a useful summary of the general health of the population.

${ }^{50}$ Australian Bureau of Statistics, Measures of Australia's Progress, (2013) < http://www.abs.gov.au/ausstats/abs@.nsf/Lookup/1370.0main+features252013> accessed 23 May 2014

${ }^{51}$ As for women and the economy, the unemployment rate is a reliable indicator in that it is considered a good measure of progress for an economy that provides jobs because it indicates the percentage of people in the labour force who are unemployed.

${ }^{52}$ Australian Bureau of Statistics, labour force (2013)

http://www.abs.gov.au/ausstats/abs@.nsf/Lookup/1370.0main+features362013> accessed on 23 May 2014

${ }^{53}$ Bill Barker, interview, October 2013

${ }^{54}$ Barker, B. 2011. Protecting, Promoting and Fulfilling Human Rights in Australia: A National Human Rights Action,

55 ibid

${ }^{56}$ A peak organization or body is an Australian term for an advocacy group with allied interests.

${ }^{57}$ Human Rights Law Resource Centre. 2011. Making rights real: A National Human Rights Action Plan for Australia, Submission to the Attorney-General's Department on the development of a National Human Rights Action Plan, February 2011, Available at < http://www.hrlrc.org.au/files/National-Human-Rights-Action-Plan-forAustralia-HRLRC-Submission.pdf $>$ 
${ }^{58}$ Barker, 2011. Protecting, Promoting and Fulfilling Human Rights in Australia: A National Human Rights Action, 13

${ }^{59}$ Australian Government, NHRAP (2004) 13

${ }^{60}$ C. Hartley, 2012. Your voice is required! Available at:

http:/www.humanrightsactionplan.org.au/nhrapblogs/your-voice-is-required-participate-in-the-development-of-thenational-human-rights-action-plan

61 ibid

${ }^{62}$ Barker, 2011. Protecting, Promoting and Fulfilling Human Rights in Australia: A National Human Rights Action, 15

${ }^{63}$ Ibid, 211

${ }^{64}$ Australian Government, NHRAP(2004) 5

${ }^{65}$ Ian PS. Anderson, Aust New Zealand Health Policy. 2006; 3: 10

${ }^{66}$ Grover, A. 2010. Report of the Special Rapporteur on the right of everyone to the enjoyment of the highest attainable standard of physical and mental health: Mission to Australia, UN Doc A/HRC/14/30/Add.4 (2010) 21-24, 10 Available at : < http://www.unhcr.org/refworld/docid/49faf7652.html > accessed on 06 June 2013

${ }^{67}$ Bill Barker, interview, October 2013

${ }^{68}$ ibid

${ }^{69}$ A. Chalabi, 'National Human Rights Action Plans: A Roadmap to Development', (2014) b The Journal of Development in Practice, 24:8, 989-1002

${ }^{70}$ Bill Barker, interview, October 2013

${ }^{71}$ Bill Barker, interview, October 2013

72 A Chalabi "The Problem-Oriented Approach to Improving National Human Rights Action Plans", (2015) The Oxford Journal of Human Rights Practice, 7 (2): 272-298

${ }^{73}$ Human Rights Law Resource Centre. 2011. Making rights real: A National Human Rights Action Plan for Australia, Submission to the Attorney-General's Department on the development of a National Human Rights Action Plan, February 2011, Available at < http://www.hrlrc.org.au/files/National-Human-Rights-Action-Plan-forAustralia-HRLRC-Submission.pdf $>$

${ }^{74} \mathrm{C}$. Hartley, 2012. Your voice is required

${ }^{75}$ Barker, 2011. Protecting, Promoting and Fulfilling Human Rights in Australia: A National Human Rights Action, 14

${ }^{76}$ Ernest R. Alexander, Approaches to Planning: Introducing current Planning Theories, Concepts and Issues, (Luxembourg: Gordon and Breach Publishers, 1995) 4

77 D. Higgins, 2011. Protecting children: Evolving systems, Family Matters 2011 No. 89, 7

${ }^{78}$ This approach is also known as networked governance and partnership governance.

${ }^{79}$ Committee on Economic, Social and Cultural Rights, UN Doc CPPR/C/AUS/CO/5 (7 May 2010)); (UN Doc A/HRC/17/10 (24 March 2011)

${ }^{80}$ Australian Government. 2012. Australia's National Human Rights Action Plan 2012, 73 Available at: http://www.ohchr.org/EN/Issues/PlansActions/Pages/PlansofActionIndex.aspx

${ }^{81}$ Department of Immigration and Border Protection, Immigration Detention and Community Statistics Summary, Department of Immigration and Border Protection, 30 November $2013<\mathrm{http}: / / \mathrm{www} . \mathrm{immi}$.gov.au/managingaustralias-borders/detention/_pdf/immigration-detention-statistics-nov2013.pdf >accessed 12 January 2014

82 ibid

83 ibid

84 ibid; Department of Immigration and Border Protection, Immigration Detention and Community Statistics Summary, 30 September $2012<\mathrm{http} / /$ cm.org.au/wmm/Resources/immigration-detention-statistics-20120930.pdf $>$ accessed 12 January 2014

${ }^{85}$ Australian Government, National Human Rights Action Plan (2012) 73

$<$ http://www.ohchr.org/EN/Issues/PlansActions/Pages/PlansofActionIndex.aspx> accessed 23 March 2013

${ }^{86}$ UNHRC, Communication No. 2094/2011 Views adopted by the Committee at its 108th session (8 - 26 July 2013), CCPR/C/108/D/2094/2011, 20 August 2013

$<$ http://tbinternet.ohchr.org/Treaties/CCPR/Shared\%20Documents/AUS/CCPR_C_108_D_2094_2011_20720_E.pd f $>$ accessed 29 March 2013

87 ibid

88 ibid

${ }^{89}$ Barker, interview, October 2013 
${ }^{90}$ Barker, 2011. Protecting, Promoting and Fulfilling Human Rights in Australia: A National Human Rights Action, 17

${ }^{91}$ S. Joseph and A Fletcher, 2012. Castan Centre For Human Rights Law: National Human Rights Action Plan: Draft Baseline Study, 9 Available at: http://www.law.monash.edu.au/castancentre/policywork/national-hr-actionplan-sub.pdf

${ }_{92}$ The Women's Legal Centre (ACT \& Region) Inc., Baseline Study Consultation, 31 August 2011, 6

${ }^{93}$ Ibid, 2

${ }^{94}$ Human Rights Law Centre Ltd, A Sound Baseline for Human Rights in Australia, 2011, Para 9 Available at : http://www.hrlc.org.au/new-human-rights-action-plan-a-step-forward-for-rights-but-needs-stronger-accountabilitymeasures

${ }^{95}$ National Human Rights Consultation summary, XXIV Available at : http://www.ag.gov.au/RightsAndProtections/HumanRights/TreatyBodyReporting/Pages/HumanRightsconsultationr eport.aspx > 10 Jan 2014

${ }^{96} \mathrm{UN}$ Doc CPPR/C/AUS/CO/5 (7 May 2010) 8

${ }^{97}$ Australian Government, NHRAP (2012) 5

${ }^{98}$ Human Rights Law Centre Ltd, A Sound Baseline for Human Rights in Australia, 2011, Para 7, Available at : http://www.hrlc.org.au/new-human-rights-action-plan-a-step-forward-for-rights-but-needs-stronger-accountabilitymeasures

${ }_{99}$ A Brown, 2012. New Human Rights Action Plan a step forward for rights but needs stronger accountability measures, 18 Dec 2012, Available at : < http://www.humanrightsactionplan.org.au/nhrap-blogs/new-nationalhuman-rights-action-plan-a-modest-success $>$

${ }^{100}$ Human Rights Law Centre Ltd, A Sound Baseline for Human Rights in Australia, 2011, Para 7, Available at : http://www.hrlc.org.au/new-human-rights-action-plan-a-step-forward-for-rights-but-needs-stronger-accountabilitymeasures

${ }^{101}$ Human Rights Council, 2011, recommendations Nos 31, 34, 94, 98, 100, 103, 108, 136

${ }^{102}$ Ibid , recommendations Nos 6-9, 11-12, 57-58, 59-65, 96, 135

${ }^{103}$ S. Joseph and A Fletcher, 2012. Castan Centre For Human Rights Law: National Human Rights Action Plan: Draft Baseline Study, 3 Available at: http://www.law.monash.edu.au/castancentre/policywork/national-hr-actionplan-sub.pdf

${ }^{104}$ Australian Government, NHRAP (2012) 25

105 ibid

${ }^{106}$ Barker, interview, October 2013

107 ibid

${ }^{108}$ Human Rights Law Centre Ltd, A Sound Baseline for Human Rights in Australia, 2011, Para 7, Available at : http://www.hrlc.org.au/new-human-rights-action-plan-a-step-forward-for-rights-but-needs-stronger-accountabilitymeasures

${ }^{109}$ ibid

${ }^{110}$ Australian Government, NHRAP (2012), 25 